\title{
International Intervention and Genocide in Bosnia
}

\author{
Yusuf Ibrahim Gamawa
}

\begin{abstract}
The United Nations intervention in the Bosnian conflict was generally considered a positive development that could bring an end to the instabilty in the Balkans after the dissolution of Yugoslavia. The UN was forced to intervene following the outbreak of violence in Bosnia after the referendum for its independence, a move that came to strongly resisted resisted by the Serbs. The UN togather with NATO collaborated on the Bosnian operations with aim of protecting the population as well as bringing stability. Arms embargo was imposed the UN, and safe areas were created, and among them them was Srebrenica. The UN declared such areas safe and free from attack when in reality it did not put in place in effective force in these areas to repel or counter attacks from any group. The result was the massacre of about 8,000 Bosnian before the UN peace keeping force by the Bosnian Serbs. The intervention in Bosnia as result raised many questions regarding $U N$ policies and role, to the extent that it is argued if the intervention was actually carried out in accordance with the established humanitarian intervention ethics and the responsibility to protect. Why did the UN declare certain areas safe when it fully aware that it lacked the ability to protect the population of the areas from attacks? Rather than protect, The UN intervene in Bosnia appeared to have created an opportunity for mass murder or what came to be known as the Bosnian genocide. This paper argues that the intervention in Bosnia fell short of complying with the principles and ethic of humanitarian interventions as will be shown in the article.
\end{abstract}

Keywords:Interventions, Bosnia, Ethics, Humanitarian, Genocide.

\section{INTRODUCTION}

It was generally thought that international intervention in Yugoslavia at the outbreak of the War that led to the dissolution of the country would be a solution that could bring an end to the violence. The violence which initially started between the Croatians and the Serbs, was to spread to Bosnia after the secession of Croatia and Slovenia. The results of the referendum in Bosnia triggered a kind of a revolt from the Serbs who were not satisfied with the results of the referendum and were not in support of independence for Bosnia. Following the break out of violence in Bosnia, the United Nations responded and attempted an intervention in Bosnia. First was the imposition of an arms embargo all over the Yugoslavian Federation, which was followed by the deployment of UN peace keeping force for the purpose humanitarian aid delivery. The UN was seen to collaborate with NATO with a view to bringing an end to human sufferings in the conflict, as a result of growing humanitarian concerns.

However, despite the efforts of the two international organizations, the conduct of the operation was openly criticized by many scholars. Hopes were dashed when despite the intervention, violence continued with increased propensity. It was seen to have escalated much more higher than its magnitude prior to the intervention. The policy of imposing arms embargo was also heavily criticized as it gave advantage to a particular side in the conflict. As a matter of fact the intervention seemed to have raised many questions regarding the manner in which it was carried out. Rather than protect and prevent, it was seen to have given room for mass murder after the creation of what came to be known as "SAFE AREAS". The UN came up with this policy and declared certain cities as safe and free from attacks when in reality it 
lacked the capacity to counter any attacks on these areas, leading to a massacre in Srebrenica of more 8,000 people under the watchful eyes of UN Peace Keeping Force.

As a result many have questioned the rationale behind the intervention, since it was very clear from the outset, the rule of engagement cannot be followed, and the UN lacked the resources and manpower required to carry out the operation. The question that readily comes to mind is why did the UN go ahead with the intervention? This paper tries to show how the Bosnian operation failed and some of the reasons attributed to this failure. The paper covered certain aspects of the ethics of international humanitarian intervention and argues that the Bosnian operation was contrary to certain aspects of these ethics and the responsibility to protect and prevent principles of military interventions. Many articles such as Stathis N. Kalyvas ans Nicholas Sambanis's article titled "Bosnia's Civil War: Origins and Violince Dynamics" and another article titled "The Role of the UN During and After the War in Bosnia-Herzegovina", with details of the role played by the UN. Humanitarian Intervention; Ethical, Legal and Political Dillemas by J.L Holzfrefe and Robert O. Keohane was among books consulted in writing this paper. Martin A. Smith's "Afghanistan in Context:NATO Out of Area Debates in the 1990's was also consulted and so is Fillippo Andreatta's "Bosnian War and the New World Order; Failure and Success of International Intervention", as well as many other sources which feature in the reference section at the end of the paper.

\section{Genesis of Instability in the Balkans}

Generally, several opinions were considered regarding the situation in the Balkan area, in an attempt to give explanation to what had led to the violence and instability in the region. Three distinctive theories had been advanced, giving insights into the likely causes, and what has led to the eruption violence in the Balkans. The most popular among such theories is that of "Ancient Hatreds". The theory according to many sources came into existence only recently, and was not in existence at the time of the former Yugoslavian republic, but emerged only recently, and was seen to be used by the Serbians and the Croatians to justify their aggression in the Balkan region ${ }^{1}$.

The second theory appears to blame the political elites for the destruction of Yugoslavia. It generally tried to explain that the elites have used nationalism to see the disintegration of Yugoslavia with the intention of consolidating their power in the States that were to emerge from the break up. Yet, the theory appeared a little weak in explaining the situation in the Balkans, even though the elites were seen and accused of embarking on media propaganda with the aim of manipulating the public. Otherwise many doubted how the educated people of the Balkans could have been manipulated by the elites ${ }^{2}$.

The third theory sees the War as arising from political, economic and social breakdown of the Yugoslavian socialist regime. Many argue that it was the deteriorating socio-economic condition that triggered the demand for some kind of radical change from the system which was viewed as unfair and unjust by majority of the people in the region ${ }^{3}$.

However, apart from these 3 theories mentioned above, trans- border crimes were also seen as largely responsible for the instability in the area. The argument had been that trans-border

\footnotetext{
${ }^{1}$ Marko Hajdinjak, “The Root Cause of Instability in the Balkans: Ethnic Hatred or Trans-Border Crime?", International Centre for Minority Studies and Intercultural Relations(IMIR),2004, p 2

2 Ibid, p 4

3 Ibid, p 4
} 
crimes provided the fertile ground for the eruption of the conflict in the Balkans. As such many tried to look at the War as a criminal rampage rather than a real War where each of members of the different groups engaged one another in a fight. Many drugs and other illegal related trade networks were expanding in the region, including trade in human beings, which replaced the trade in oil. The system of trade was seen to have transformed from State run businesses to a Mafia one, based on smuggling of illicit good and human beings. Such trade enabled international organized crimes groups such as the Italian Mafia and the Turkish and Middle Eastern drug smuggling networks to establish their presence in the region, adding to the vicious cycle of corruption and organized crime ${ }^{4}$. UN findings showed that crimes committed in the name of ethnic cleansing were carried out by the most marginal elements of society who formed Para-military groups, which were influenced, armed and encouraged by political leaders using nationalism and historical grievances for revenge. It was alleged that no more than 66,000 thugs were involved in fighting and killings in the former Yugoslavia. So many claimed that it was not a War of say between 5 Million people where each and everyone had taken up arms against the other ${ }^{5}$. Or that all the Serbs, Croats and the Bosnian Muslims had all been engaged in fighting one another. The crimes it appeared, had been carried out by a small group from among the Serbian population with the support and influence of the elites.

\section{Clash of Civilisations}

Considering the situation in the Balkans, one is prompted to consider the works of Samuel Huntington on the Clash of Civilizations. This is due to the fact whatever we may say about the Balkan conflict, the truth remains that elements of civilizations were used to justify either the War or even if it was a criminal rampage. And as clear shown above, though the theory of "Ancient Hatred" has been disputed, yet the fact that it was admitted that the elites used nationalism and historical grievances for revenge in the latter part clearly shows that indeed, problems had existed between the groups to an extent as demanding revenge among the groups. And it appears these were basically civilizational grievances and not elite based or political grievances. So, at this point one cannot completely dismiss the Ancient Hatred theory among factors responsible for the conflict in the area.

And although Huntington's theory may not have come as exactly predicted by him, or in the scale at which he claimed the civilization changes may take place as criticized by many ${ }^{6}$, but that many cases appeared, and many other potential cases are in sight in different parts of the world is enough evidence to at least accept the theory in analyzing ethnic and religious conflicts even if we do not accept his theory in its totality. The central theme of Huntington's theory is that culture and cultural identities, which at the broadest level are civilization identities, are shaping the patterns of cohesion, disintegration and conflict in the Post Cold War world. People according to Huntington identify with cultural groups, tribes, ethnic groups, religious communities, nations and at the broadest level, civilization. According to Huntington, religion is the central defining characteristic of civilization and that civilization rests on religion ${ }^{7}$. He seemed to have dismissed the idea that of universal civilization, and concluded that humanity is divided into sub-groups, tribes, nations and broader cultural entities known as civilizations. The theory categorized the world into 7 different civilizations, which include

\footnotetext{
4 Ibid, p 17

5 Ibid,p 6

${ }^{6}$ Lietenant Commander A M Kudrotullah, Psc, BN, "The Clash of Civilisations: Validity of Samuel P Huntington's Thesis in Contemporary World", p 17

7 Ibid, p 4
} 
Western Sino (Chinese), Japanese, Hindu, Islamic, Orthodox, and Latin American and offers the possibility that an African civilization may be the eighth ${ }^{8}$. He maintained that all frontier Wars between Orthodox and Islamic civilizations including Bosnia and Chechnya are part of the conflict of civilizations, and that these conflict according to him cannot be resolved because the combatants belong to different civilizations?

\section{BACKGROUND OF THE BOSNIAN CONFLICT}

Yugoslavia's President, Tito during his time was able to suppress ethnic sentiments in the politics of Yugoslavia. However, after his death in 1980, the system changed in Yugoslavia, and power now began to rotate among certain leaders selected by the Assembly of Yugoslavia. This marked the beginning of the rise of nationalist sentiments in the country. By 1985, certain organizations had openly condemned the party and Tito, who they blamed for anti-Serbs policies in Yugoslavia for three decades. These according to these groups were visible in terms of income and what they termed genocide attempt by the Albanian majority in Kosovo, as a result of anti Serbs policies. While the dissatisfaction continued, Slobodan Milosevic, the head of the Communist party conveyed a speech in Kosovo that had a mass appeal, which gave him the needed support to defeat the opposition. As President of Serbia, pursued a policy that limited the autonomy of Kosovo, and in 1990 dissolved the autonomy of Kosovo Assembly, which came to be ruled by Serbia. Following this development, the ethnic Albanians declared the independence of Kosovo. The split of the league of Communists along ethnic lines made clear growing nationalist intolerance in the country, with clear signs of a looming conflict ${ }^{10}$.

The Federal elections which the then Prime Minister Ante Markovic hoped would hold could not hold as Slovenia and Serbia boycotted the very idea itself. The elections that took place in Slovenia in April 1990, saw the drafting of a new constitution that was preparing the secession of Slovenia. This was followed by a campaign for autonomy by Croatia. Amidst such an atmosphere, Milosevic declared that if Yugoslavia disintegrated, all Serbs would come under a single government. The declaration of the Croatian Krajina Serbs' independence followed Milosevic's declaration. The declaration was supported and recognised by Serbia. And by june 1991, Croatia and Slovenia had declared their independence from Yugoslavia. In August, war broke out between the Croatian militias and the Serbs over the control of Vukovar and Dubrovinik cities. And in September 1991, the United Nations authorized a 14,000 Peace Keeping Force into former Yugoslavia, and imposed an embargo on Serbia in accordance with UN Resolution 713, which led to a cease fire agreement in 1992. Mainly arising from the support of Germany, EU States recognized the independence of Croatia and Slovenia, but tended to ignore Bosnia, where the tendency for ethnic conflict was likely to arise, awaiting the results of a referendum on independence ${ }^{11}$.

And once the votes were counted, and a Muslim majority appeared to be on the lead, while the Serbs were opposed to the result which was in favor of independence, it resulted in the Serbs taking to the streets, blocking the Bosnian Muslims off from the Serbian country side. Next, the Bosnian Serbs set up a Parliament, which was followed by a massive movement of Serbs out of the Bosnian dominated cities. And by April, the United States and other European States had recognized Bosnia as an independent State. However, the continued Serbs aggression resulted in a sanction by the UN on Serbia and Montenegro in May 1992. By the summer of 1992,

\footnotetext{
8 Ibid, p 5

9 Ibid, p 5

${ }^{10}$ Stathis N. Kalyvas and Nicholas Sambanis, "Bosnia’s Civil War: Origins and Violence Dynamics", Yale University, (2001):191-193

${ }^{11}$ Ibid:191-193.
} 
humanitarian crisis in Bosnia had led to the deployment of UN Forces for the delivery of humanitarian aid. A no fly zone was imposed over Bosnia. In May 1993, the UN declared Sarajevo, Srebrenica and 2 other cities as "safe areas" under the protection of the UN. NATO agreed to use air power to protect UN Forces if attacked by the Serbs who continued their aggression, which eventually faced NATO's threat of air strike. In the spring of 1995, the Serbs attacks on the "safe areas" led to the massacre or what many called "genocide" of Bosnian Muslims in Srebrenica. Following this, US President Clinton called on NATO and the UN to reaffirm their commitment to protect safe areas, and the allies threatened air strike if safe areas were further attacked. With continued Serbs aggression on safe areas, NATO undertook a month long intensive bombing campaign, which was followed by a peace negotiation led by the United States or the Dayton Agreements, which was signed in Paris on December 14, 1995 and which saw to the end of the Bosnian War ${ }^{12}$.

\section{Defination and Ethics of Humanitarian Interventions}

Humanitarian intervention is defined as the threat or use of forces across State borders by a State or group of States, aimed at preventing or ending widespread and grave violations of fundamental human rights of individuals other than its own citizens, without the permission of the State within whose territory force is applied. However, there are two approaches to this term and they include; non forcible interventions, such as the threat or use of economic, diplomatic sanctions, and forcible interventions aimed at protecting or rescuing the intervening State's own nationals ${ }^{13}$.

Several arguments have been advanced regarding the ethic of humanitarian interventions, and if the international community has the moral duty to intervene with the purpose of ending massive human rights violation. These arguments have been categorized in various ways by different scholars such as Michael J. Smith, who distinguishes political realist views and liberal views, J. Bryan tried to differentiate moral and legal arguments, whereas Mark R. Wicclair contrasts rule oriented and consequences-oriented ones, and other scholars made different categorizations, but these remained the dominant views.

The first ethical divide has to with proper source of moral concern, here Naturalist theories of international justice contend that morally binding international norms are an inherent feature of the world; a feature that is discovered through reason and experience. These theories argue that facts about the world possess intrinsic moral significance which human beings are powerless to alter. And in contrast, Consensualist theories of international justice claim that moral authority of any given international norm derives from the explicit or tacit consent of the agents subject to that norm. And on these views, norms are made, not discovered, they are the products of consent and so only binding on the parties to an agreement ${ }^{14}$.

The second ethical divide is related to the appropriate objects of moral concern-individualists theories of international justice are concerned ultimately only with the welfare of individual human beings. And in contrast, Collectivist theories of international justice maintain that groups-typically ethnic groups, races, nations, or States are proper objects of moral concern. However, the Collectivists view groups entirely in non aggressive terms, without reference to

\footnotetext{
12 Ibid:191-193.

${ }^{13}$ J.L Holzgrefe and Robert O. Keohane, Humanitarian Intervention; Ethical, Legal and Political Dillemas (Cambridge University Press 2003), 18

${ }^{14}$ Ibid: $18-25$
} 
the rights, interests or preferences of the individuals that compose them. In other words, Collectivists hold that groups can have interests' independent of, and potentially in conflict with those of their members.

The third ethical divide concerns the exact weight of moral concern. Egalitarian theories of international justice claim that the objects of moral concern must be treated equally. By this, they mean that no object of moral concern should count for more than any other object of moral concern. Inegalitarian theories, in contrast, require or permit them to be treated unequally. And the last ethical divide has to do with the proper breadth of moral concern. Universalist theories assert that all relevant agents, wherever they exist, are the proper objects of moral concern. Particularist theories, in contrast, hold that only certain agents, some human beings, but not others; some races, nations, States, but no others are the proper objects of moral concern ${ }^{15}$.

In discussing international interventions in practical terms adherence to international justice is not only necessary but inevitable, though it will not be wrong to look at all ethical devides and see the differences as well there concerns. It is true that in all conflicts, one side must be the aggressor, and in such a situation, what is to be done? Would both sides be treated equally? So as can be seen proper understanding of conflicts and implications of actions is required to be able to know what to do exactly when faced with certain situations such as the Bosnian conflict. But I will rather agree that all parties in all conflicts are objects of moral concerns, and that interventions are carried out not with the aim of causing harm to any party in any conflict even if it was the aggressor, but rather interventions are seen to be carried out to prevent and to protect, either side from more harm or from being harmed, or to put a stop to the process, by any means possible, including the use of force as a last resort. It is only at such stage that harm to any party can be possible but even then it is not intended, but it is done if all all effort has failed to convince one party to stop aggressive acts that is seen to be harming the population. The above ethical devides provide us with broad views on conflicts and justice and provide us with an understanding and ability to distinguish them and find solution to them, just as the principles below will explain. It is believed that this will help understand the intervention in Bosnia by the UN and NATO more properly.

The basic principles and the responsibility to protect clearly state that sovereignty implies responsibility, and the primary responsibility for the protection of its people lies with the State itself. And where a population is suffering from serious harm, as a result of internal War, insurgency, repression or state failure, and the State in question is unwilling or unable to halt or avert it, the principle of non-intervention yields to international responsibility to protect. The foundations of the responsibility to protect, as a guiding principle for the international community lies in the fact that obligations must be inherent in the concept of sovereignty. And that the responsibility of the UN Security Council, under Article 24 of the UN Charter, for the maintenance of international peace be observed. Also specific legal obligations under human rights and human protection declarations, covenants and treatise, international humanitarian law and national law be followed. The developing practice of States, regional organizations and the Security Council itself all constitute the guiding principles for the international community with regards to the responsibility to protect.

Elements of the responsibility to protect embrace three specific responsibilities. These include the responsibility to prevent; to address both the root causes and direct causes of internal

${ }^{15}$ Ibid: $18-25$ 
conflict and other man made crisis putting population at risk. The responsibility to react; To respond to situations of compelling human need, with appropriate measures, like sanctions and international prosecutions and in extreme cases military intervention. And the responsibility to build; To provide, particularly after military intervention, full assistance with recovery, reconstruction and reconciliation, addressing the causes of the harm the intervention was designed to halt or avert. The priorities of intervention must be mainly prevention, it is the single most important responsibility to protect; Prevention options must always be exhausted before intervention is contemplated, and more commitment and resources must be devoted to it. And that the exercise of the responsibility to both prevent and react should always involve less intrusive and coercive measures being considered before more coercive and intrusive ones are applied.

The main principles for military intervention must be seen to be in accordance with the Just Cause Threshold; Military intervention for human protection purposes is an exceptional and extraordinary measure. To be warranted, there must be serious and irreparable harm occurring to human beings, or imminently likely to occur, such as large scale loss of life, actual or apprehended, with genocidal intent or not, which is the product either of deliberate state action, or state neglect or inability to act, or a failed state situation. Large scale 'ethnic cleansing', actual or apprehended, whether carried out by killing, forced expulsion, acts of terror or rape. Precautionary Principles are also extremely important in all interventions. First is the Right intention. The primary purpose of the intervention, whatever other motives intervening states may have, must be to halt or avert human suffering. Right intention is better assured with multilateral operations, clearly supported by regional opinion and the victims concerned. Military intervention is always viewed as the last resort. It can only be justified when every non-military option for the revention or peaceful resolution of the crisis has been explored, with reasonable grounds for believing lesser measures would not have succeeded. And it must be of proportional means: The scale, duration and intensity of the planned military intervention should be the minimum necessary to secure the defined human protection objective. There must be some reasonable prospects in such an intervention. There must be a reasonable chance of success in halting or averting the suffering which has justified the intervention, with the consequences of action not likely to be worse than the consequences of inaction.

There is no better or more appropriate body than the United Nations Security Council to authorize military intervention for human protection purposes. The task is not to find alternatives to the Security Council as a source of authority, but to make the Security Council work better than it has. Security Council authorization should in all cases be sought prior to any military intervention action being carried out. Those calling for an intervention should formally request such authorization, or have the Council raise the matter on its own initiative, or have the Secretary-General raise it under Article 99 of the UN Charter. The Security Council should deal promptly with any request for authority to intervene where there are allegations of large scale loss of human life or ethnic cleansing. It should in this context seek adequate verification of facts or conditions on the ground that might support a military intervention. The Permanent Five members of the Security Council should agree not to apply their veto power, in matters where their vital state interests are not involved, to obstruct the passage of resolutions authorizing military intervention for human protection purposes for which there is otherwise majority support. And if the Security Council rejects a proposal or fails to deal with it in a reasonable time, alternative options are: I, consideration of the matter by the General Assembly in Emergency Special Session under the "Uniting for Peace" procedure; and II, action 
within area of jurisdiction by regional or sub-regional organizations under Chapter VIII of the Charter, subject to their seeking subsequent authorization from the Security Council. The Security Council should take into account in all its deliberations that, if it fails to discharge its responsibility to protect in conscience-shocking situations crying out for action, concerned states may not rule out other means to meet the gravity and urgency of that situation - and that the stature and credibility of the United Nations may suffer thereby.

The operational Principles of military interventions must be followed in all military operations. There must be clear objectives; clear and unambiguous mandate at all times; and resources to match. Common military approach among involved partners; unity of command; clear and unequivocal communications and chain of command are all necessary. Acceptance of limitations, incrementalism and gradualism in the application of force, the objective being protection of a population, not defeat of a state Rules of engagement which fit the operational concept; are precise; and reflect the principle of proportionality; and involve total adherence to international humanitarian law. Acceptance that force protection cannot become the principal objective. There must be maximum possible coordination with humanitarian organizations ${ }^{16}$.

\section{The United Nations Intervention in Bosnia}

The United Nations only became involved in the Bosnian conflict when it imposed an arms embargo on the entire Yugoslavian republic through UN Resolution 713 in September 1991. There were atleast three main reasons why the UN involvement came very late. First, the UN was at the time primarily occupied with the Gulf War. Secondly, the crisis did not appear very serious from the beginning, and thirdly, the Balkan area was an area that was considered to be under the influence of the European Community, and it was expected that it was an issue that the EC could deal with. And it is known that the EC had shown effort in dealing with the crisis after it called for a Conference on Yugoslavia, which was chaired by UK's former Foreign Secretary ${ }^{17}$. The UN's involvement in the arms embargo also generated a lot of criticisms from many quarters, both within and outside Yugoslavia. It was a policy that was seen to have been partial, and appeared to favor the Serbs, who inherited most of the military equipments of the former Yugoslavian republic. While the Croatian and Bosnian Muslims had only light weapons, and yet the embargo was enforced despite the fact that they lacked tanks and air crafts, which the Serbs had, and which ensured their superiority in the conflict. In October 1991, the UN Secretary General appointed an Envoy to Yugoslavia to broker a cease fire in the Croatian hostilities. The Envoy, Cyrus Vance, a former U.S Secretary of State, succeeded in temporary settlement of the crisis under what came to be known as the Vance plan. The UN Resolution 743 established the United Nations Protection Forces to be deployed to certain parts of the former Yugoslavia, with its headquarters at Sarajevo ${ }^{18}$ in order to maintain a neutral position.

It was generally expected that the United Nation's presence in Bosnia after it had established its headquarters in Sarajevo, would put an end to the Bosnian conflict. However, this did not happen due a number of reasons as full scale fighting, particularly after the Bosnian referendum on independence. First, it must be understood that the mandate initially establishing UN presence did not permit the UN to participate in many areas, the mandate however expanded to include; take over control of the Sarajevo airport for the purpose of humanitarian supplies, support the UN High Commissioner for Refugees to deliver aid to

\footnotetext{
${ }^{16}$ Ibid

17 See "UN Secretary General's Report Pursuant to UNSC Resolution 749", (1992): 11, http://daccessdds.un.org.docs/RESOLUTION/GEN/N92/202/18/PDF/N9220218.pdf/

${ }^{18}$ Glenny, M, "The Fall of Yuogoslavia”, Boston College Third World Law Journal Vol 14, Issue 2, (1994):20
} 
various destinations in Bosnia, and protect convoys of International Committee of Red Cross transporting released civilian detainees. Despite the expansion of these mandates, several problems persisted. The UN Forces were not heavily armed, and were at the same time low in number, and were thus vulnerable themselves, and could not participate in any armed conflict, especially against the Serbs who were heavily armed. And besides enforcement was not part of the UN mandate, just as fighting any of the three groups will likely be seen to constitute taking sides in the conflict. Therefore, the first activity that the UN became involved in, was the brokering of ceasefires, which never took effect, as a result of the weak nature of the UN Forces. All the sides did not respect any ceasefires brokered by the UN, nor any operation the UN is involved. The UN Forces accompanying humanitarian convoys were on many occasions returned back or have their contents confiscated by Serbian forces at gun point and it was an indication that the conditions for peace keeping have not been fulfilled, and that troops were undermanned and poorly armed. Other problems were related to breaches of the resolution or violations, as policies and coordination sometimes became contradictory ${ }^{19}$.

The UN made a lot of mistakes by not properly equipping the UN Peace Keeping Force and increasing their number, as this led and rendered all UN policies ineffective and useless. The UN imposed a no fly zone over Bosnia, but could not enforce it. At worst UN troops could only monitor compliance. About 465 violations were monitored, and in March 1993, enforcement was considered and was coordinated by NATO, even then it did not mean immediate halt to violations. Between April-June, the UN mandate was extended and "Safe Areas" were created. With the creation of "Safe Areas" ${ }^{20}$, people in these areas expected UN Forces to protect them and ensure their safety. But the UN troops were not armed in reality and cannot therefore provide the protection needed to have declared these areas "Safe Areas." In 1994, a mortar attack killed 68 people in market in Sarajevo. Following the NATO bombing of Udbina airport after the Serbs attacked Bilhac using air craft from Croatian Serb base. The Serbs reacted by taking MORE 360 UN soldiers as hostages, showing the helplessness of the UN Force in Bosnia. Safe Areas, Zepa and Srebrenica fell in July 1995 . And Srebrenica witnessed a massacre of civilians that was not seen since World War II. The Srebrenica massacre if anything proved that all UN policies, succeeded only if the Bosnian Serbs accepted or made them binding out goodwill. Safe Areas became safe only when they choose not to attack, and became unsafe when they choose to attack. The UN Peace Keeping Force could not stop or even challenge the Bosnian Serbs militarily.

Generally, the UN Force Mission was seen to have failed in Bosnia for several reasons. The Mission it should be understood was understaffed. The number of troops for the Mission was very low. And this made it impossible for the UN troops to function as expected. The Mission also faced a lot of financial problems during the operation. The Peace Keeping accounts totaled 1.26 Billion USD, while unpaid assessments amounted to 2.236 Billion USD. The Mission was not armed and was designed as peace keeping Mission. This put the Mission at the mercy of warring factions and the Mission became hostages or puppets in the hands of local War Lords $^{21}$. After NATO bombings in 1995 for example, the Bosnian Serbs reacted by taking over

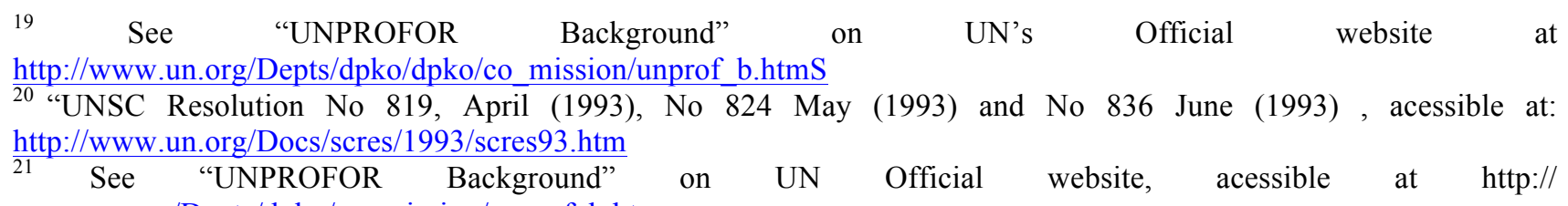
www.un.org/Depts/dpko/co mission/unprof b.htm 
360 UN soldiers as hostages, and chained them, showing clearly the defencelessness of the UN force. ${ }^{22}$ The UN Representatives were not willing to get UN troops involved deeper in the conflict. And as a result of such open failure, there were calls for the withdrawal of the UN Force from Bosnia, which later came to be considered by the UN Secretary General. Even though the forces were not withdrawn immediately, NATO undertook the bombings of the Bosnian Serbs siege of Safe Areas, forcing the Serbs to accept peace proposal, which was followed by the Dayton Agreements as well as the termination of the UN Force Mission, and its replacement by a new Mission with a timelier mandate.

\section{NATO and the Bosnian Conflict}

It was in fact the UN that actually put a lot of pressure on NATO and eventually dragged it into participating in the Bosnian conflict. Despite the seemingly lack of connection between NATO and UN, the fact that the UN Secretary General Boutros Ghali had come up with a policy that would see regional security organizations getting involved in conflict management, made it possible for NATO to become involved in the Bosnian conflict. The UN Secretary General in 1992 requested NATO support for UN humanitarian relief operations in Bosnia, and NATO responded by dispatching 2 naval task forces under it and WEU respectively to Bosnia. Further requests by the UN were carried out swiftly. One of the most significant operational decisions made in 1992, was the deployment of Western European military personnel to help in escorting and protecting UN aid convoys on the ground in Bosnia. Multinational headquarters Staff were dispatched to facilitate command and control. In December 1992, NAT0 received a letter from the UN Secretary General, in which he requested for NATO support for future UN Resolutions in the Bosnian conflict. NATO responded positively and agreed to support the UN on a case by case basis and in accordance with NATO procedures and peace keeping operations under the authority of the UN Security Council ${ }^{23}$.

It was the first time that NATO was getting involved in peace keeping operations since its establishment. U.S Vice President Dick Cheney however remained confident regarding NATO's ability, making reference to numerous complex operations undertaken by NATO in the past, which made peace keeping appear very easy. Dick Cheney's statement did not take into account the reality that NATO had only assisted UN Forces during the Gulf War, and that NATO member states did not devote much time to think and strategize on the Bosnian conflict. And as such NATO states did not actually understand from the beginning what the Bosnian operations entail. Due mainly to this fact, the conflict from 1992-1995 came to be characterized by stresses and Strains; operational factors worsened the situation, and the UN Forces on the ground found it difficult to conduct humanitarian relief operations even as security situation worsened. The mandate and peace keeping principles of impartiality and consent rendered the UN Forces helpless and the operations ineffective. Even in Safe Areas requisite troop numbers and rules of engagement were not provided ${ }^{24}$.

\footnotetext{
${ }^{22}$ Malcolm N, Bosnia-A Short History (Macmillan Publishers 1994),262

${ }^{23}$ Vos Henk, "Co-operation in Peacekeeping and Peace Enforcement", Brussels, North Atlantic Assembly

(NATO), Sub-Committee on Defence and Security Co-operation between Europe and North America, (1993):11. See also Leurdijk Dick, "Before and after Dayton: the UN and NATO in the former Yugoslavia", Third World Quarterly, vol.18, no. 3 (1997): 459.

${ }^{24}$ Martin A. Smith, "Afghanistan in Context: NATO Out of Area Debates in

The 1990's”, Royal Military Academy, UNISCI Discussion Papers, № 22 (2010):8-7.
} 
There were several problems between NATO and the UN regarding the operations in Bosnia. The use of air power remained part of such problems. There were disagreements about what air power to use. In 1993, NATO was authorized to device plans for possible air strikes against the Bosnian Serbs military positions and bases. The UN on the other hand maintained that the request was for close air support to protect UN personnel on the ground. As a result, it created a friction between NATO and the UN, especially with regards to the "dual key arrangement for authorizing the use of air power". The UN had used the key to block air strikes several times ${ }^{25}$. NATO had always considered itself as an autonomous organization, and did not take permissions or orders from the UN. And this came to be confirmed when Willy Claes became the Secretary General of NATO. Willy was seen as an undiplomatic character, and was quoted as saying "by working with the UN in Bosnia, NATO had made itself ridiculous as a military organization $^{26 "}$. He was further quoted as saying " if we cannot we cannot set the rules for our military operation, they will have to find other idiots to support peace keeping" ${ }^{27}$. And from then he declared that NATO's actions will be independent of the UN in the operations. The UN did not entirely trust the intentions of NATO, as contained in the memoirs of Michael Rose, the UN Operations Commander in Bosnia. The UN could not understand NATO's insistence on bombing the Bosnian Serbs positions. But for NATO credibility remained an issue of concern. The decision to make large scale strikes against the Bosnian Serbs military bases in August and September 1995, was seen as reinforcing NATO's credibility, which was uncertain in public eyes $^{28}$. A statement was issued declaring the determination of the alliance to implement decisions as well as its resolve to see to the end of the conflict. Following the Dayton Agreements for peace, attention was turned to deploying a multinational force to supervise the implementation of its military provisions.

\section{Causes of International Failure in Bosnia}

The failure in Bosnia has been explained at two levels of analysis, which have to do with the changing dynamics of the Post Cold War politics ${ }^{29}$. At the domestic, because the War was not perceived as constituting an international threat, States tended to rely on their internal public opinion on whether to participate or not. Many democratic governments feared losing elections for putting its army and their lives on the line. An example is the Clinton administration, and how it conducted itself towards the Bosnian conflict. As such domestic considerations were seen to have hindered the United States from intervening or at least contributing in the conflict. The EC mediator, Lord David Owen was quoted as saying "we were by now acutely aware of the reluctance of Defense Ministers in all NATO capitals except Ankara to take new commitments, and I knew that there was no support for suggestions that our troops should have their mandates extended beyond that of escorting convoys, for example to a role in stopping ethnic cleansing" ${ }^{\prime 30}$. At the end of the Cold War most countries were reluctant to throw themselves into uncertainties as well as commit resources to such a venture. This was further compounded by the setting up of unrealistic standards by the international community for resolving the crisis, as well as lack of proper understanding of the conflict by most European countries.

\footnotetext{
${ }^{25}$ Rose General M., "Fighting for Peace",( Harvil Press 1998),10-209.

${ }^{26}$ Quoted in "Each State for Itself”, Financial Times, 6 January, 1995.

${ }^{27}$ Ibid

28 "Press Release", North Atlantic Treaty Union, (95) 73 and (95) 79, NATO Press Services, Brussels,(1995).

${ }^{29}$ Fillippo Andreatta, "The Bosnian War and the New World Order: Failure and Success of International Intervention",(1997):6-7.

${ }^{30}$ David Owen, Balkan Odyssey, (Victor Gollancz 1995,:6-55.
} 
At the international level, the Bosnian War did not challenge the fundamental interests of many countries, unlike during the Cold War when the Soviet threat could involve all countries in the Western alliance. As a result the conflict was viewed with a different concern by various countries. The multi polar system which emerged after the Cold War was characterized by increased diffusion of power, and in such a system, the multiplicity of actors makes alignments less firm, actors have to spread their resources across counterparts, and cannot concentrate them on a single dimension. In such systems, alliances are not structurally determined as in a rigid bipolar system. But this is not to say that all multi polar systems are unstable, but that their stability requires a diplomatic effort to which major powers have to adjust to. The result was that it led to quarrels between various powers, particularly between the United States, Europe and Russia, which in the end rendered international pressure less effective ${ }^{31}$.

This apart, most countries wanted to share the benefits of international stability and glory by providing peace in Bosnia, yet no State was willing to be committed or pay the price for such effort. Rather it tended to complicate matters with regards to proposed settlements, which had to satisfy different interests and views. And for this, the international organizations became victims. Since organizations only deepen cooperation among States, but cannot bring about cooperation if States are unwilling to cooperate. These organizations found themselves in conflict between objectives and capabilities of the various members. And as such the United Nations, NATO and the EU were entrusted with missions which they were not capable of performing as long as States were not committed. Both the UN and NATO did not have any reasonable strategy and clear policy direction regarding the conflict. While the UN was bent on peace keeping, NATO on the other hand was keen on attack, leading to a clear conflict between the two organizations ${ }^{32}$. The EU on its part, feels it has more right to be involved in the conflict, but even then, it could not come up with a common policy on Bosnia. The Bosnian Muslims it appeared fell victims to moral hazard and to unrealistic expectations of foreign support which could have diminished the chance for an early settlement. International institutions it would appear relied on abstract principles and which looks deliberate, due to a process of difficult consensus building among members ${ }^{33}$.

\section{The Bosnian Genocide}

As mentioned at the beginning of this work, after the death of Tito, the Yugoslavian President, a War broke out between Serbia and Croatia in 1991, which had a profound effect on BosniaHerzegovina. The regime of Milosevic which succeeded Tito, directed a military attack by the Yugoslavian army and Serbian Militias on Bosnian towns, which led to a full scale War between the ethnic Serbs and Bosnian Muslims in Bosnia -Herzegovina. Earlier the elections in Bosnia in 1990 had led to the defeat of the Communist Party, and thereafter the three political parties came into fierce competition with one another ${ }^{34}$. These parties include Karadzic's SDC and the Croats Nationalist HDZ, which were under the control of the Milosevic regime in Serbia. The two parties appeared to have been heavily funded and armed by the Milosevic regime. With the

\footnotetext{
${ }^{31}$ Fillippo Andreatta, "The Bosnian War and the New World Order: Failure and Success of International Intervention”, (1997):8-9.

32 Ibid: $8-10$

${ }^{33}$ Ibid: $9-10$
}

${ }^{34}$ Gearoid 0 Tuathail, John O Loughlin, “After Ethnic Cleansing: Return Outcomes in Bosnia-Herzegovina A Decade Beyond War", Institute of Behavioral Sciences University of Colorado, 2009, p 5. 
War unfolding in Bosnia-Herzegovina around May 1992, Karadzic addressed the Bosnian Serbs and articulated six strategic goals for the army of the republic of Srprska, the new army of Yugoslavia in Bosnia. Part of the goals was that the three constituents of Bosnia-Herzegovina should be separated, while the rest of the goals had to do with the border arrangements necessary for such separation ${ }^{35}$. It was reported however that the aim of the War was in keeping up the vision of the Serbian Interior Ministry, of the creation through the use of force of an ethnically homogenous State in Bosnia, republic of Srprska and the unification of both into a newly reconstituted Yugoslavia that would be centred on an exclusionist Serbian identity ${ }^{36}$. Such agenda justified the violence that saw the expulsion of other ethnic groups from their homes to create a new State of an ethnically homogenous people. A kind of a violent geo-political engineering was to prepare the ground for the War, which was characterized by drugs, alcohol, human trafficking, revenge and several other criminal activities. Ethnic cleansing was carried out in Bosnia-Herzegovina mainly by armed formations affiliated with the SDS and the VRS. The HDZ and the HVO, which were all political groups, became engaged in the ethnic cleansing during the War with the Croats and the Bosnian Muslims between 1993$1994^{37}$. By 1995, the UN intervened and came up with policies that tended to promote the Serbian intention of genocide. The creation of "Safe Areas", which followed the arms embargo that ensured the superiority of the Serbs on not only the Bosnian Muslims, but the UN forces as well, made it very easy for the genocide in Bosnia to happen with so much ease. In July 1995, Srebrenica which was declared a Safe Area by the UN was invaded by Serbian forces, in the presence of UN forces, and the result was the massacre of more than 8000 Bosnian Muslims, men and boys ${ }^{38}$. Thousands of men were executed and buried in mass graves, hundreds of men were buried alive, and many men and women were mutilated and slaughtered, children killed before the eyes of their mothers ${ }^{39}$. It was estimated that a total of about 100,000 Bosnian Muslims died in the conflict, with more than a million people displaced, and the War came to an end after NATO undertook the bombing of Serbian formations, which forced the Serbs to accept the peace proposal, which was marked by the Dayton peace Accords in November 1995.

\section{The International Court and the Bosnian Genocide Case}

It is considered important to from the beginning understand what genocide actually means, and not only that, it is also significant to understand what the genocide convention adopted by the United Nations and signed by member nations clearly outlined about the numerous acts that are considered to constitute genocide. It is only after an understanding of the proper meaning of the word and the ruling by the UN on what constitutes an act of genocide that we can properly understand the Bosnian genocide case or even even understand if genocide was actually commited in Bosnia, or even be able to establish the actual perpetrator of such genocide. Prior to 1944 the term genocide was not in existence and was said to have originated thereafter. The term gencoide came to be understood as a specific term referring to violent crimes committed against a group. A Jewish lawyer Raphael Lewkin (1900-1954) first sought to describe Nazi policies of systematic murder and the destruction of European Jews. And Raphael it was reported formed the word genocide by conbining "geno" a Greek word that

\footnotetext{
35 Ibid, p 6

36 Ibid, p 6

37 Ibid, p 7

38 Helen Gulgun Bukulmez, "The Begging Question: Can the ICJ Be Trusted To Punish the Perpetrators if the UN is Partly Responsible for the Bosnian Genocide?", Advanced Legal Writing and Research \& International Law Thesis, Chase College of Law, 2009, p 17

39 Ibid, p 3
} 
means race and "cide", a Latin word that means "killing". Raphael according to sources may have been trying to explain a coordinated plan of different actions that were aimed at destroying the essential foundations of the life of certain national groups, with the aim of annihilating the groups, when he proposed the new word. And that in 1945 the International Military Tribunal at Nuremburg, Germany charged Nazi officials of crimes against humanity. It was at the tribunal that the word genocide first appeared and was listed among the indictments in a rather descriptive term than legal term ${ }^{40}$.

On 9 Decemeber 1948, the convention on the prevention and punishment of genocide came to be adopted by the United Nations. Article I of the convention came to describe genocide to mean any act that is committed with the intent of destroying in whole or in part a national, ethnical, racial or religious group. The convention came to explain that acts that include among others killing members of the group, causing serious bodily or mental harm to members of the group, or deliberately inflicting on the group conditions of life calculated to bring about its physical destruction in whole or in part, and imposing measures intended to prevent births within the group or forcibly transfering children of the group to another group as constituting acts of genocide. ${ }^{41}$

The genocide convention further states in article III that acts such as conspiracy to commit genocide, direct and public incitement to commit genocide, including attempt to commit genocide or complicity in genocide are acts that are punishable. Article VI of the convention also states clearly that persons charged with genocide or any other acts enumerated in article III shall be tried by a competent tribunal of the state in the territories of which the act was committed, or by an International panel tribunal as may have jurisdiction with respect to those contradicting parties, which shall have accepted its jurisdiction. Again article IX explains that disputes between contracting parties relating to the interpretation, application or fulfilment of the present convention, including those related to the responsibility of a state for genocide or any other acts enumerated in article III, shall be submitted to the International Court of Justice at the request of any of the parties to the dispute. And it was largely based on article IX that the Bosnian genocide case was filed at the International Court of Justice by the Bosnians accusing the Serbs of acts of genocide in the Bosnian conflict.

It could be recalled that Bosnia-Herzegovina filed a case before the International Court of Justice in 1993, in which it claimed that during the conflict in former Yugoslavia, which after 2001 became Serbia and Montenegro, were responsible for mass killings and other and other crimes against Bosnian Muslims, which is seen as a violation of the genocide convention. The Bosnians generally claimed that the Serbians, under the pretense of protecting Serbian population in Bosnia-Herzegovina, supported and armed certain groups which carried out killings and other crimes that constituted acts of genocide against the Bosnian Muslims. The Bosnians claimed that the Serbians shared a vision of a greater Serbia, following which a plan was conceived on how to achieve such a vision through ethnic cleansing. In response to these claims filed by the Bosnian Muslims, the Serbians admitted to having committed certain War crimes that were totally against humanity, but denied that such crimes were committed with genocidal intentions. Serbia further denied the number of deaths claimed by the Bosnian Muslims, and at the same time refuted claims that Serbia should bear the blame, arguing that

\footnotetext{
40 What is genocide?, Defination of genocide, Origin of the term genocide, www.usmm.org/confrontgenocide/defining-genocide

41 United Nations, The Convention on the Prevention and Punishment on the Crime of Genocide, Article II, UN Treaty Series No 1021.
} 
the atrocities were committed by the army of Srprska (VRS), the Bosnian Serb entity that had the control over a wide area after Bosnia seceded from Yugoslavia ${ }^{42}$.

The International Court of Justice made its position known on the case concerning the Application of the Convention on the Prevention and Punishment of the Crime of Genocide (Bosnia-Herzegovina v. Serbia and Montenegro) on the 26 February, 2007. The court held that the mass murder of Bosnian Muslims at Srebrenica in July 1995 amounted to genocide, but the court failed to find Serbia responsible or complicit in the genocide. The court however established that Serbia had violated the genocide convention by failing to prevent the massacre, as well as failing to punish those responsible for the killings in Srebrenica ${ }^{43}$. The judgment was seen to have generated a lot of reactions, with many criticizing the judgment, while several others applauded the judgment, many found it difficult to understand how the court found Serbia as violating the genocide convention and yet not guilty of genocide, others saw the judgment as clearly indicating that Serbia had orchestrated the genocide, and yet many others were disappointed with the judgment for not what they see as confusing, not addressing certain issues but as there is no clear winner in the case.

Following the arguments between Bosnia-Herzegovina and Serbia, the International Court of Justice confirmed that it has been established with full conclusive evidence that members of the protected group were victims of massive mistreatments, beatings, rape and torture causing bodily and mental harm during the conflict and at the detention camps, which is exactly what constitutes genocide. Several observations were made regarding the rulings of the court. First, was that despite the fact that the court established the Serbs were involved in the atrocities committed against the Bosnian Muslims, nevertheless the court said it could not find Serbia responsible for the genocide crime as stated by the court; "there is much evidence of direct or indirect participation by the official army of the FRY, along with the Bosnian Serb armed forces, in military operations in Bosnia-Herzegovina in the years prior to the events in Srebrenica", and further it stated that; "the FRY was in a position of influence over the Bosnian Serbs who devised and implemented the genocide in Srebrenica.....owing to the strength of the political, military and financial links between FRY on the one hand and the republic Srprska and the VRS on the other hand, whose relationship though somewhat weaker than in the preceding period, nonetheless remained close" ${ }^{\prime 4}$. It should be noted that the statements above emanating from the court has clearly identified those responsible for the genocide against the Bosnian Muslims, and the statements are in clear contradiction with the courts position when it said it could not find Serbia responsible for the atrocities committed.

The court generally argued that there wasn't sufficient evidence to prove Serbia's role in committing the genocide, the court rejected Bosnia's suggestions that it merely had to prove its case on the balance of probabilities, arguing that the claims against any state must be proved by evidence that is fully conclusive. The court insisted that it had to be fully convinced that allegations of genocide or complicity in genocide were clearly established. The court's judgment also appeared to have raised doubts, especially with regards to the standards in the judgment, just as it was seen to have refused to compel Serbia to produce and turn over unedited copies of the Supreme Defense Council documents, which could have provided the

\footnotetext{
${ }^{42}$ Ibid, p 2

43 Susana SaCouto, "Reflections on the Judgement of the International Court of Justice in Bosnia's Genocide Case against Serbia and Montenegro", 2007, p 2

${ }^{44}$ Ibid, p 3
} 
needed evidence to prove Serbia's guilt in case. These documents contain the minutes of meetings of the Supreme Defense Council of Serbia, the highest decision making body of Serbia. The documents have been described as the best inside view of Serbia's role in the Bosnian War between 1992-1995 ${ }^{45}$. The court was seen to have applied higher standards in the determination of the case that it has to be established beyond doubt that Serbia was involved in these acts. And even though the court had clearly stated that in the absence of a smoking gun evidence of intent, the tribunal can derive genocidal intent from circumstantial evidence, which include among others; pattern evidence of abuses against the protected group. It is important to note here that 3 separate examples and instances of such intent could have been used by the court to reach a decision on the genocide issue ${ }^{46}$. The systematic rape of women, the massive maltreatments in detention camps outside Srebrenica and the attacks on historical, cultural and religious heritage of the Bosnian Muslims could have added to the analysis of the genocide intent. But the court was seen to have overlooked all these evidences in taking a position for many years until $2007^{47}$. This is also despite the fact that the court agreed to accept evidences from UN reports, submissions from States, and from government and nongovernmental organizations, as well as newspaper articles and expert witnesses, which it agrees will be persuasive. Yet, the court was not seen to have relied on the evidences from these sources in determining the case. There were doubts as to the ability of the court to fully analyze all evidences before it. In some cases it relied on the judgement of the ICTY ( International Criminal Tribunal for Former Yugoslavia), which found in its analysis the lack of genocidal intent, here the court is seen not to have carried out an independent cumulative analysis of all the evidences before, as carried out by ICTY in reaching a decision on the case.

As observed right from the beginning of the trial, the Tribunal had been reluctant to admit the crime of genocide against many of the people that were accussed of the crime despite the fact that evidences were provided in many instances. The court appeared to have been more comfortable to refer to such accusations as crimes against humanity instead of the crime of genocide. And here the case against Dusko Tadic is a case in point. Dusko it was reported was arrested in Germany and was charged by the German courts of aiding and abetting genocide, torture, murder and believed to have caused bodily harm. Dusko it is believed had played a significant role in the Bosnian war crimes. It became surprising how the tribunal was quick to dismiss the charges of genocide by the German court against Dusko, claiming that the German courts did not have any evidence to make such claims against him. It is significant here to note that the Tribunal was quick to jump to the defence of Dusko when the Deputy Prosecutor was quoted as saying that "they were going to attempt to prove it solely on the basis of testimony of an expert witness. But we thought that it would be difficult to establish genocide with respect to Dusko Tadic."

Again in October 1995, the Tribunal was invited to include the charge of genocide, after hearing evidence of ethnic cleansing in the case between the Prosecutor V. Nikolic. The Prosecutor it was noted refused to accept or add such a suggestion despite the fact that the suggestion was made after the Tribunal had been invited to an evidence of ethnic cleansing against the said offender, Nikolic. It was perhaps in 1996 that the Tribunal appeared to have accepted any genocide indictment. The Tribunal by itself at this time showed evidence that Serb leaders Radovan Karadzic and Ratko Mladic had plans or intent of driving Muslim Croat peoples from previously mixed populated areas with a view to creating an "ethnically

\footnotetext{
45 Ibid, p 3

46 Ibid, p 4

47 Ibid, p 4
} 
cleansed" Serb region in Bosnia. The Tribunal further admitted that the evidences and testimonies at that particular point in time had shown the active participation of the highest political and military leaders in commiting various crimes by the Bosnian Serb military and Police forces in detention facilities. The Tribunal believed that Radovan and Ratko aided and planned the execution of genocide in the various detention facilities. The Tribunal therefore found that liability on the basis of command responsibility has been established.

Here, it should be noted and understood that the Tribunal had failed to find the Serbian authorities or state guilty of the crime of genocide despite admitting that that the highest political and military leaders among the Serbs were involved and had indeed been found guilty, with evidence of commiting act that constituted the crime of genocide. The Tribunal confirmed that liability has been established on the basis of command responsibility. Here one does not need an official letter, document or directive by the Serbian authorities or admitting that it has committed genocide in Bosnia before it can be accepted that the Serbian state was indeed guilty of genocide. It appears that is the only evidence that would appear acceptable to the Tribunal, and it is such an evidence that couldn't have ever been found. Governments generally consist of institutions, systems and people running such institutions and systems established. People everywhere in positions of authority are seen to be representing the various institutions they run, and these institutions were established by the government and in effect the individual running or representing these institutions are directly or indirectly representing the government. The government or state is not an individual, but people and institutions generally represent and act on behalf of a government or a state who are part and parcel of it. And likewise their actions or inactions represent the actions or inactions of that particular government or state they represent through the various institutions they run or represent and on whose behalf they carry out certain decisions or actions. To distinguish or try to separate individuals from the institutions or governments they represent in a situation as the Bosnian genocide is not only improper, but is to shy away from the reality of what has happened and the consequences that should have followed. And failing which will result in difficulty of finding a lasting peace between the two groups, since clearly an aggressor has been identified. To reduce the crimes commited by the Serb leaders through recognised government or state institutions to individual offences, is to undermine the extent and level to which these crimes were commited. The Tribunal should have considered and looked at the roles these individuals played through the various institutions they represent and the government or state that these individuals and institutions represent in reaching any conclusion regarding the genocide in Bosnia.

It was further observed with disappointment that after about six years of the establishment of the Tribunal, only about 8 suspects out of more than seventy public indictments were accused of genocide. Here the manner in which the Tribunal openly rejected the charge of genocide against Serb leaders was a source of concern regarding the overall confidence reposed on the Tribunal in the dispensation of justice. Many were surprised and perplexed when the former Serbian leader Milosevic was charged with crimes against humanity instead of genocide, especially with regards to the Kosovar Albanians in 1999. As a matter of fact, the many instances of the Tribunals failure to admit genocidal indictment against certain people were recorded and appear to have undermined the credibility and competence of the Tribunal. The case of Goran Jelisica is seen as a reference to such practices in the Tribunal. Jelisica was believed to have been responsible for the murder of several people in the concentration camps at Brcko, north-west of Bosnia Herzegovina. He was arrested and charged with the crime of genocide, which he denied, but admitted and pleaded guility to crimes against humanity. 
Initially, a trial had proceeded with a view to a genocide conviction, and after an evidence had been led, the trial chamber announced that it would enter an acquital on the charge of genocide. The prosecutor himself was shocked at the manner in which the trial chamber dismissed the genocide indictment and was of the opinion that the trial chamber had already rendered judgement ven before the case was properly heard by the tribunal. And an appeal regarding the case was made in 2001, but the trial chamber claimed that returning the case for hearing would not be in the interest of justice, and for this reason the acquittal was allowed to stand. The trial chamber appeared to have been satisfied with Jelisic's pleading guilty to crimes against humanity and appeared to have wondered why the prosecutor was insisting on the genocide charge.

Another case in point, related to the persecution in concentration camps which the trial chamber was seen to have granted a defence motion to dismiss the charge of genocide against Sikirca. The trial chamber was seen to have dismissed the charge after evidence was heard, and a few days later Sikirca agreed and pleaded gulity of crimes against humanity and was consequently convicted. It was after the prosecutor had failed on two occassions to obtain a genocide conviction that in 2001, the trial chamber convicted General Radislav Krstic of genocide. Radislav was found guilty of the massacre of more than 7000 male Bosnian Muslims in Srebrenica in July 1995. And he was to become the first individual to have been convicted by the tribunal for the crime of genocide.

\section{CONCLUSION}

There is no doubt that deep rooted ethnic sentiments may have been responsible for the conflict in the Balkan region, including Bosnia-Herzegovina, among several other factors as discussed in the paper. The theory of ancient hatred gives an indication to this, which became further confirmed by the growing nationalism among the various groups as well as the violence that followed. And at the same time trans-border crimes cannot be dismissed as having prepared the grounds for the disorderliness and violence as explained in the paper. Trade in drugs, tracking in human beings and several other crimes were seen to have come about as a result of these border crimes. This also saw the emergence of cartels and the mafia in the region who had close affiliation with some of the political leaders, and as a result saw to the formation of gangs which were armed and controlled by these leaders, and it was very easy to use this groups in perpetrating violence in the region.

International intervention in Bosnia as can be seen is in clear violation of the basic principles and ethics of international humanitarian intervention. Agreed Post Cold War politics brought some changes in the international system which affected the operation both at the international and domestic levels. However it should be noted that these changes could not have affected the ability of the UN to take rational decisions or actions regarding the conflict. The indecision and disagreements between member nations did not stop the UN from examining the consequences of the operation objectively. Here also one can say that the decision to intervene has violated the precautionary principle of reasonable prospect of averting human suffering, such that the consequences of intervention will not be higher than non intervention. In the Bosnian case, genocide was seen to occur after the intervention, and before the very eyes of the UN Forces that declared Srebrenica a "safe area". Rather than prevent human suffering or avert any potential danger, the intervention appeared to create more dangerous situations that created opportunities for further killings and sufferings. Here two precautionary principles were violated, apart from the principle of reasonable prospect that of proportional means was also violated, the UN Forces were inferior to the Serb forces militarily, and the principle states that the scale, intensity and duration should be the maximum necessary to secure the objective of human protection. Other violations which were 
admitted and shown in this paper were in terms of operational principles, the UN's mandate in Bosnia remained unclear and confused for quite some time, and the lack of resources both in terms of personnel, equipment and funds to match the scale of the intervention is so evident. The open disagreement between the UN and NATO is also a clear violation of the operational principle of common approach, unity of command and chain of command with participating partners in operations. At a point NATO declared its decisions independent of the UN. Above all, the violation of the principle of incrementalism and gradualism after the intervention was seen as the sole reason that rendered the operation and ineffective, and the operation by violating this principle completely failed in the Bosnian operations. This in terms of application force, even when UN convoys delivering humanitarian aid were attacked and harassed by the Serbian force, till a moment when UN soldiers were taken hostage, the UN did not take any decisive action of either deploying more troops or otherwise to match the Serb forces superior fire power, and for this the UN intervention appeared empty and without any significance. And here one would say that not intervening would have been better than the intervention as it led to more danger, suffering and deaths. The decision and steps taken to intervene by the UN, has made the UN deep necked in the blame for all that happened in Bosnia, irrespective whatever else that may have happened between states, regarding resources or troops. The whole blame should be on the UN, fully aware of all the disagreements between states and scarcity of resources went ahead to intervene, when it knew it could not, and was not in a position to, and lacked the capacity to do so, in clear violation of the precautionary principles and ethics of international humanitarian intervention. Here one must confess that with regards to the genocide in Srebrenica, the UN indirectly facilitated it through its policies and its incapacity when it put arms embargo and at the same time declared some place safe areas, including Srebrenica, when it knew it could not offer any protection against the Serb forces. The UN may not have deliberately come up with these policies to support the massacre of the Bosnian Muslims, but in reality the policies aided the genocide, otherwise the Bosnian Muslims would have remained where they were only to be killed right before helpless UN forces.

The case filed by Bosnia in the International Court also appeared to have been a case of justice delayed, is justice denied. The case had been filed since 1993, but the court was only able to deliver judgment in 2007. It took the court about 14 years to take a decision on the case, when all the arguments had been very clear right from the beginning. What could have been responsible for such delay? And though after these years the judgment confirmed that the Srebrenica massacre amounted to genocide, the court failed to find Serbia guilty. Who then was responsible for the genocide? How possible is that? This then raises the question of how the court arrived at such a conclusion that it was genocide without knowing the particular group responsible. Since everyone knows that genocide happens when an attempt is made to eliminate or displace a particular group, and of course it must be by another group. So how did the court go about analyzing how the genocide occurred without coming face to face with the perpetrators? The court did identify during the proceedings all the groups involved in the killings and other atrocities, but yet said it didn't find any group guilty, what manner of judgment is that? In such a case where one party has filed a case against another accusing him of certain crime, and a court establishes that such a crime has occurred, it is only logical for one to be found guilty of that crime, otherwise the case remains inconclusive. And for this, the genocide case remains open until the court is able to establish which was guilty of the crime which it said was committed, otherwise the court must explain how it came about the facts, with which it based its decision, without knowing which group was responsible. And as mentioned previously, the Tribunal had failed to find the Serbian authorities or state guilty of the crime of genocide despite admitting that that the highest political and military leaders 
among the Serbs were involved and had indeed been found guilty, with evidence of committing acts that constituted the crime of genocide. The Tribunal confirmed that liability has been established on the basis of command responsibility. Here one does not need an official letter, document or directive by the Serbian authorities or admission on the part of the Serbs that they committed genocide in Bosnia before the tribunal will accept that the Serbian state was indeed guilty of genocide.

\section{References}

Ana Devic, Transnationalization of Civil Society in Kosovo; International Local Limits of Peace and Multiculturalism, Ethnopolitics, Routledge,2006.

Burak Gunes, Genocide Case, Strategic Outlook, February 2013

Bojana Blagojevic, Causes of Ethnic Conflict; A Conceptual Framework, Journal of Global Change and Governance, Volume III, No 1, 2009.

Didem Ekinci, The War in Bosnia-Herzegovina and Turkish Parliamentary Debates (1992-1995): A Constructivist Approach, Ululararasi Iliskiler, Vol 6,No 22, 2009.

Doja Ulas Eralp, Turkey and Bosnia-Herzegovina: A Future Reflecting on The Past. SETA Policy Brief, No 10, August 2010.

Fillippo Andreatta, The Bosnian War and the New World Order; Failure and Success of International Intervention, 1997.

Gerard Toal, John 0' Loughlin, After Ethnic Cleansing; Return Outcomes in Bosnia- Herzegovina A Decade Beyond War, Annals Association of American Geographers, Vol 99, No 5, 2009.

J.L Holzgrefe and Robert O. Keohane, Humanitarian Intervention; Ethical, Legal and Political Dilemmas.Cambridge, 2003.

Jonathan Fox, State Failure and the Clash of Civilisations; An Examination of the Magnitude and Extent of Domestic Civilisational Conflict From 1950-1996, Australian Journal of Political Science, Vol 38, No 2.pp195-213.

John Steinbruner, George Kenney, Michael Klare, Michael Mazarr, U.S Intervention in Ethnic Conflict, Policy Papers, No12, Institute on Global Conflict and Cooperation,1995.

Lietenant Commander A.M. Kudrollah, PSC,BN, The Clash of Civilisations: Validity of Samuel P. Huntington's Thesis in Contemporary World.

Marija Dordeska, Between Myths and Reality-Macedonia Between Turkey and the European Union.

Marko Hajdinjak, The Root Cause of Instability in the Balkans; Ethnic Hatred or Trans-border Crime?, International Centre for Minority Studies, 2004.

Martin A. Smith, Afghanistan in Context: NATO Out of Area Debates in the 1990'S, UNISCI Discussion Papers.

Oisin Tansey, Democratisation Without a State; Democratic Regime Buliding in Kosovo, Democratisation, Routledge, 2007.

Sharyl Cross, Russia and NATO Towards the $21^{\text {st }}$ Century; Conflicts and Peace Keeping in Bosnia-Herzegovina and Kosovo, 2001.

Stathis N. Kalyvas and Nicholas Sambanis, Bosnia's Civil War;Origins and Dynamics.

Steven Woehrel, Bosnia-Herzegovina;Current Issues and U.S Policy, Congressional Research Service, 2013.

Steven L. Burg, Intervention in Internal Conflict; The Case of Bosnia, Brandeis University.

Susana SaCouto, Reflections on the Judgement of the International Court of Justice in Bosnia's Genocide Case Against Serbia and Montenegro.

Sylvie Gangloff, Turkish Policy Towards the Conflict in Kosovo; The Pre-eminence of National Political Interest.

Sylvie Gangloff, The Relations Between Turkey and Macedonia: The Incoherencies of Political Partnership, Turkish Review of Balkan Studies, No 6, 2001,pp37-56.

Pieter Van Houten, Stefan Wolf, International Organisations and the Settlement of Ethnic Conflicts in the Western Balkans:Common Goals, Different Approaches?, Third ECPR Conference, Budapest, 2005. 
Timo Kivimaki, Marina Kramer and Paul Pasch, The Dynamics of Conflict in the Multi-Ethnic State of BosniaHerzegovina, Country Conflict Analysis Study,March 2012.

www.ceeisaconf.ut.ee/orb, The Role of UN During and After the War in Bosnia-Herzegovina. 